\title{
Oestradiol levels in sheep plasma during the oestrous cycle
}

\author{
R. J. Scaramuzzi* and R. B. Land \\ M.R.C. Unit of Reproductive Biology, University of Edinburgh, \\ 39 Chalmers Steet, Edinburgh, EH3 9ER, and \\ A.R.C. Animal Breeding Research Organization, \\ West Mains Road, Edinburgh EH3 3JQ, U.K.
}

\begin{abstract}
Summary. The concentration of oestradiol was measured by radioimmunoassay in ovarian venous plasma collected from ewes of three breeds (Finnish Landrace, Scottish Blackface and Tasmanian Merino) on Day 9 of the oestrous cycle and in jugular venous plasma collected daily around oestrus in two of these breeds. The mean \pm s.e.m. concentration in the ovarian venous plasma of the Merino $(44.1 \pm 7.6 \mathrm{pg} / \mathrm{ml})$ was lower than that in Blackface $(72 \cdot 2 \pm 10 \cdot 2 \mathrm{pg} / \mathrm{ml})$ and Finn ewes $(66.8 \pm 10 \cdot 2 \mathrm{pg} / \mathrm{ml})$. The overall fitted mean concentration in peripheral venous plasma was $1.7 \mathrm{pg}$ oestradiol-17//ml, with no difference between the Finn and Blackface ewes, in which the highest preovulatory values were $3.9 \pm 0.5$ and $3.4 \pm 0.5 \mathrm{pg} / \mathrm{ml}$ respectively.
\end{abstract}

\section{Introduction}

Variation in the ovulation rate of the ewe has been postulated to be associated with changes in the sensitivity to oestrogen of the negative and positive feedback loops which regulate ovulation (Land, Wheeler \& Carr, 1976; Land, 1976). Indirect support for this concept can be seen in the delayed (in relation to the onset of oestrus) preovulatory discharge of LH (Thimonier \& Pelletier, 1971; Land, Pelletier, Thimonier \& Mauléon, 1973; Bindon, Blanc, Pelletier, Terqui \& Thimonier, 1975), the smaller and later release of LH by ovariectomized ewes treated with oestrogen (Land et al., 1976), and the increased tolerance to exogenous oestrogen (Land, 1976) of sheep with high ovulation rates. Such a reduction in the sensitivity of the hypothalamic-pituitary system to the negative feedback of oestrogens would be expected to be accompanied by increased circulatory levels of LH, oestradiol-17 $\beta$ or both. Published data are few, but suggest that if there are differences in LH they are small (Land $e t$ al., 1973). The evidence for oestrogen is conflicting: Bindon et al. (1975) did not observe any difference in the concentration of oestrogen in the peripheral plasma of breeds of sheep with differing ovulation rates, while we have reported differences in the rate of secretion of oestrogen from the autotransplanted ovaries of ewes with different ovulation rates (Baird \& Scaramuzzi, 1976a; Wheeler, Baird, Land \& Scaramuzzi, 1978). The following experiments were conducted to study the concentrations of circulating oestradiol-17 $\beta$ during the oestrous cycle in three breeds of sheep with different ovulation rates.

\section{Materials and Methods}

Twelve ewes each of the Finnish Landrace, Scottish Blackface and Tasmanian Merino breeds (ovulation rates 2.9, 1.3 and 1.0 respectively; Wheeler \& Land, 1977) were subjected to laparotomy on Day 9 of the oestrous cycle (oestrus = Day 0 ). Anaesthesia was induced with sodium pentobarbitone and maintained with halothane, the ovaries and their pedicles were exposed via a mid-ventral incision, and the number of corpora lutea in each ovary was recorded. Ovarian venous blood $(20 \mathrm{ml})$ was collected into heparinized $20-\mathrm{ml}$ syringes by needle puncture ( 23 gauge) of the ovarian vein about

\footnotetext{
* Present address: C.S.I.R.O., Division of Animal Production, P.O. Box 239, Blacktown, New South Wales 2148, Australia.
} 
midway between the ovary and the junction of the utero-ovarian vein. In a second experiment, $50 \mathrm{ml}$ blood were withdrawn, by jugular venepuncture into heparinized tubes, from 15 ewes of the Finnish Landrace and 15 of the Scottish Blackface breeds. The samples were taken daily at 09:00-11:00 h for 18 days during the breeding season. The ewes were run throughout with keeled vasectomized rams and the identity of oestrous ewes was recorded daily. In both experiments the blood was centrifuged at $4^{\circ} \mathrm{C}$ within $1 \mathrm{~h}$ of collection, and the plasma was removed and stored frozen until assay.

Oestradiol-17 $\beta$ was measured by a radioimmunoassay (Baird, Burger, Heavon-Jones \& Scaramuzzi, 1974) adapted for sheep ovarian venous blood (Baird, Swanston \& Scaramuzzi, 1976) or sheep jugular venous blood as follows. Plasma $(20 \mathrm{ml})$ was extracted once with 2 volumes of purified (peroxide free) redistilled diethyl ether. The organic layer was removed, evaporated to dryness under nitrogen and the residue redissolved in $2 \mathrm{ml} \mathrm{2,2,4-trimethylpentane} \mathrm{saturated} \mathrm{with} \mathrm{ethylene} \mathrm{glycol.}$ The extract was then subjected to celite column chromatography (Baird et al., 1974). The fraction containing oestradiol-17 $\beta$ was evaporated to dryness under nitrogen and dissolved in $0.3 \mathrm{ml}$ phosphatebuffered saline containing $0 \cdot 1 \%(\mathrm{w} / \mathrm{v})$ gelatin and then assayed for oestradiol- $17 \beta$ by the method described by Baird et al. (1974). Procedural losses were monitored by the addition of $1000 \mathrm{~d} / \mathrm{min}$ of $\left[6,7-{ }^{3} \mathrm{H}\right]$ oestradiol-17ß (sp. act. $46 \mathrm{Ci} / \mathrm{mmol}$; Radiochemical Centre, Amersham, U.K.) to the $20 \mathrm{ml}$ plasma before extraction. The overall recovery of $\left[{ }^{3} \mathrm{H}\right]$ oestradiol-17ß was estimated by using $0.05 \mathrm{ml}$ (one-sixth) of the final extract. The antiserum $\left(R_{1} B_{3}\right)$ to oestradiol-6-BSA was raised in rabbits and selected because of its high affinity and specificity: there was negligible cross-reactivity with all steroids tested (oestradiol- $17 \beta, 100 \%$; oestradiol $-17 \alpha, 0.4 \%$; oestrone, $1.4 \%$; oestriol, $0.5 \%$ ). The overall recovery of a typical assay was $62 \pm 6 \%(n=20)$. The blank for $20 \mathrm{ml}$ water was $0.11 \pm 0.03$ (s.e.m.) $\mathrm{pg} / \mathrm{ml}(n=18)$. The inter-assay precision measured on a pool of ram plasma was $1 \cdot 33 \pm 0 \cdot 15$ $\mathrm{pg} / \mathrm{ml}(n=11)$. The assay was capable of detecting as little as $0 \cdot 1 \mathrm{pg}$ oestradiol $-17 \beta / \mathrm{ml}$.

\section{Results}

The concentrations of oestradiol in the ovarian venous plasma and the ovulation rates of the sheep of the three breeds are shown in Table 1 . The overall mean concentration in the Merinos was signifcantly lower than that in the Blackface ewes $(t$ test, $P<0.05)$ and the difference from that in the Finns approached significance ( $t$ test, $0 \cdot 05<P<0 \cdot 1$ ). The Finn and Blackface ewes did not differ from each other, and differences between left and right ovaries and between ovaries with or without corpora lutea were not statistically significant $(P>0.05)$ (Table 1$)$. Of the 12 failures out of 72 attempts to collect ovarian venous blood (Table 1) a large proportion (8) were from ovaries that did not contain corpora lutea and this accounts for the fewer failures among the Finnish Landrace ewes. The observed ovulation rates (Table 1) are of the same order as those given in more extensive reports (Wheeler $\&$ Land, 1977).

The concentration of oestradiol-17 $\beta$ in peripheral plasma was assayed throughout the oestrous cycle for the ewes of the Finnish Landrace breed, but only around oestrus for most of the Blackface ewes. The comparison of the two breeds is therefore restricted to the period from 5 days before to 4 days after oestrus. Analysis of variance with least squares techniques indicated that there was no interaction between breed of ewe and day of the oestrous cycle, and this source of variation was omitted from further analyses. The estimation of main effects, the analysis of variance of which is summarized in Table 2, showed that there were significant differences between days of the oestrous cycle. The mean oestradiol concentration increased progressively until the day before oestrus when it was higher than on all other days but there were no other differences among the days (Table 2). The analysis indicated that there was no significant difference between the two breeds over this period of the oestrous cycle, giving a least squares fitted mean concentration of $1.7 \mathrm{pg}$ oestradiol $-17 \mathrm{\beta} / \mathrm{ml}$. The s.e. of the difference $(0.06 \mathrm{pg} / \mathrm{ml})$ was 0.135 . Individual ewes showed random fluctuations in the concentration of oestradiol-17 $\beta$ during the luteal phase of the oestrous cycle. These luteal maxima are about 3-4 times the basal concentration recorded but lower than the preovulatory peaks (Table 3). The preovulatory peak was slightly higher $(13 \%)$ in the Finns than in the Blackface ewes. 
Table 1. The concentration (mean \pm s.e.m., no. of samples in parentheses) of oestradiol-17 $\beta$ in ovarian venous plasma collected on Day 9 of the oestrous cycle, and ovulation rates in three breeds of sheep (12 ewes per breed)

\begin{tabular}{lccc}
\hline & $\begin{array}{c}\text { Finnish } \\
\text { Landrace }\end{array}$ & $\begin{array}{c}\text { Scottish } \\
\text { Blackface }\end{array}$ & $\begin{array}{c}\text { Tasmanian } \\
\text { Merino }\end{array}$ \\
\hline Successful bleedings & $22 / 24$ & $19 / 24$ & $19 / 24$ \\
\hline $\begin{array}{l}\text { Ovulation rate } \\
\quad \text { Mean } \\
\text { Range }\end{array}$ & $\begin{array}{c}4.2 \pm 0 \cdot 5 \\
3-9\end{array}$ & $\begin{array}{c}1 \cdot 5 \pm 0 \cdot 2 \\
1-3\end{array}$ & $1 \cdot 0 \pm 0 \cdot 0$ \\
\hline $\begin{array}{l}\text { Total oestradiol } \\
\quad \text { pg/ml) conc. }\end{array}$ & $66 \cdot 8 \pm 10 \cdot 2(21)$ & $72 \cdot 2 \pm 10 \cdot 2(18)$ & $44 \cdot 1 \pm 7 \cdot 6(18)$ \\
Right ovary & $77 \cdot 0 \pm 16 \cdot 4(11)$ & $71 \cdot 2 \pm 12 \cdot 6(10)$ & $49 \cdot 5 \pm 11 \cdot 5(8)$ \\
Left ovary & $55 \cdot 6 \pm 10 \cdot 4(10)$ & $73 \cdot 5 \pm 17 \cdot 8(8)$ & $39 \cdot 8 \pm 11 \cdot 1(10)$ \\
Ovary with CL & $70 \cdot 8 \pm 10 \cdot 5(19)$ & $75 \cdot 3 \pm 11 \cdot 8(11)$ & $40 \cdot 7 \pm 10 \cdot 1(10)$ \\
Ovary without CL & $40,17(2)$ & $67 \cdot 4 \pm 19 \cdot 7(7)$ & $48 \cdot 4 \pm 12 \cdot 2(8)$ \\
\hline
\end{tabular}

Table 2. The concentrations $(\mathrm{pg} / \mathrm{ml})$ of oestradiol-17 $\beta$ around oestrus in the peripheral plasma of ewes of the Finnish Landrace and Scottish Blackface breeds

\begin{tabular}{lcccccccccc}
\hline & \multicolumn{10}{c}{ Day of oestrous cycle } \\
\cline { 2 - 11 } Breed & -5 & -4 & -3 & -2 & -1 & 0 & 1 & 2 & 3 & 4 \\
\hline Finns & $1.2 \pm 0.3$ & $1.9 \pm 0.5$ & $1.6 \pm 0.3$ & $1.8 \pm 0.3$ & $3.1 \pm 0.6$ & $2.3 \pm 0.5$ & $1.4 \pm 0.4$ & $1.4 \pm 0.5$ & $1.8 \pm 0.3$ & $2.4 \pm 0.5$ \\
& $(6)$ & $(7)$ & $(6)$ & $(8)$ & $(10)$ & $(10)$ & $(9)$ & $(9)$ & $(7)$ & $(7)$ \\
Blackface & - & $1.3 \pm 0.9$ & $1.8 \pm 0.6$ & $2.0 \pm 0.3$ & $2.8 \pm 0.6$ & $1.2 \pm 0.5$ & 1.2 & 1.7 & 1.0 & - \\
& & $(5)$ & $(9)$ & $(9)$ & $(9)$ & $(9)$ & $(3)$ & $(3)$ & $(3)$ & \\
\hline
\end{tabular}

Values are mean \pm s.e.m., no. of ewes in parentheses.

Analysis of variance

\begin{tabular}{lrrr}
\hline \multicolumn{1}{c}{ Source } & d.f. & MS & F \\
\hline Breed & 1 & 0.47 & $0 \cdot 21$ \\
Ewe within breed & 13 & $2 \cdot 29$ & 1.69 \\
Day of oestrous cycle & 12 & 3.03 & $2 \cdot 20^{*}$ \\
Remainder & 104 & 1.35 & \\
\hline
\end{tabular}

$$
* P<0.05
$$

Table 3. The concentrations of oestradiol-17ß (mean \pm s.e.m. of daily samples, no. of observations in parentheses) during the oestrous cycle in two breeds of sheep

\begin{tabular}{lcc}
\hline & \multicolumn{2}{c}{ Breed of ewe } \\
\cline { 2 - 3 } & Finnish Landrace & Scottish Blackface \\
\hline $\begin{array}{l}\text { Maximum conc. } \\
(\mathrm{pg} / \mathrm{ml})\end{array}$ & $3.9 \pm 0.5(10)$ & $3.4 \pm 0.5(9)$ \\
$\begin{array}{l}\text { Maximum conc. during luteal phase } \\
(\mathrm{pg} / \mathrm{ml})\end{array}$ & $2.7 \pm 0.3(22)$ & $3.0 \pm 0.8(7)$ \\
$\begin{array}{l}\text { Minimum conc. during luteal phase } \\
(\mathrm{pg} / \mathrm{ml})\end{array}$ & $0.9 \pm 0.1(28)$ & $0.8 \pm 0.2(7)$ \\
\hline
\end{tabular}




\section{Discussion}

The radioimmunoassay for peripheral oestradiol-17 $\beta$ described is able to measure lower oestradiol levels than similar assays used by previous workers (Bindon et al., 1975; Yuthasastrakosol, Palmer \& Howland, 1975; Pant, Hopkinson \& Fitzpatrick, 1977) and it provided accurate and precise estimates of the peripheral concentration of oestradiol-17 $\beta$. Less than $10 \%(17 / 183)$ of all samples assayed contained $>4 \mathrm{pg}$ oestradiol $-17 \beta / \mathrm{ml}$ and about $10 \%(21 / 183)$ of all samples contained $<0.5 \mathrm{pg}$ oestradiol $-17 \beta / \mathrm{ml}$, and $80 \%$ of all samples taken from ewes of both breeds therefore fell within the narrow range of $0.5-4.0 \mathrm{pg}$ oestradiol $-17 \beta / \mathrm{ml}$. The patterns of oestradiol $-17 \beta$ concentrations observed in individual sheep of both breeds suggest the random occurrence of peaks throughout the luteal phase of the oestrous cycle. The blood sampling frequency of once per day does not allow the frequency or size of these oestradiol- $17 \beta$ peaks to be estimated accurately, especially as it is known that oestradiol peaks can occur with a frequency as high as one peak every $2 \mathrm{~h}$ (Baird et al., 1976) and that these peaks occur in response to pulsatile LH release (Baird et al., 1976; Scaramuzzi \& Baird, 1977).

The results show that, in two breeds of sheep (Finn and Blackface) with vastly different ovulation rates, the pattern of oestradiol as assessed from daily blood samples is surprisingly similar and confirms the earlier brief report of Bindon et al. (1975). The concentration in the ovarian vein did, however, differ, the Merino, with the lowest ovulation rate of the three breeds studied, having the lowest oestradiol concentration on Day 9 of the oestrous cycle. The ovarian venous concentrations of oestradiol in Finn and Blackface ewes did not differ; however, differences in secretion rate might have been masked by differences in blood flow because the blood flow to an ovary with a single corpus luteum (CL) is almost twice that to an ovary without a CL (Baird \& Scaramuzzi, 1976b). This is compatible with the breed differences in secretion rates of oestradiol from the autotransplanted ovary when studjed at frequent intervals of $6 \mathrm{~h}$ (Baird \& Scaramuzzi, 1976a) and 0.5 h (Wheeler et al., 1978) over short periods. In the present study the failure to detect or infer breed differences in peripheral oestradiol levels may be the result of the failure to measure blood flow for the ovarian venous data or the infrequent (daily) sampling of peripheral blood from a relatively small sample of animals.

The present and earlier data (Land et al., 1973; Bindon et al., 1975) lead to the conclusion that endocrine measurements need to be made in greater detail than those presently available. For example, oestradiol secretion in sheep varies dramatically with variation in endogenous pulsatile $\mathrm{LH}$ discharges (Baird et al., 1976; Scaramuzzi \& Baird, 1977). The hormone concentration in a single daily blood sample cannot detect small, but possibly important, variations in the frequency and/or amplitude of hormone discharge, and is therefore unlikely to give a true indication of hormone patterns.

The problems posed, the identification of the source of variation in ovulation rate and the direct critical testing of the hypothesis that ovulation rate is associated with variation in the negative feedback control of the release of gonadotrophins, still await resolution.

We wish to acknowledge the expert technical aid of Sandra Henderson, Marjorie Fordyce, D. W. Davidson, W. G. Davidson, R. D. Preece and G. J. Lee. The antiserum $\left(R_{1} B_{3}\right)$ to oestradiol-17 $\beta$ was provided by Dr S. G. Hillier of the Tenovus Institute, Cardiff.

\section{References}

Baird, D.T. \& ScaramuzzI, R.J. (1976a) Changes in the secretion of ovarian steroids and pituitary luteinizing hormone in the peri-ovulatory period in the ewe: the effect of progesterone. $J$. Endocr. 70, 237-245.

BaIrd, D.T. \& SCaramuzzi, R.J. (1976b) The source of ovarian oestradiol and androstenedione in the sheep during the luteal phase. Acta endocr., Copenh. 83, $402-409$.
Baird, D.T., Burger, P.E., Heavon-Jones, G.D. \& ScaramuzzI, R.J. (1974) The site of secretion of androstenedione in non-pregnant women. $J$. Endocr. 63, 201-212.

Baird, D.T., Swanston, I. \& Scaramuzzi, R.J. (1976) Pulsatile release of $\mathrm{LH}$ and secretion of ovarian steroids in sheep during the luteal phase of the estrous cycle. Endocrinology 98, 1490-1496. 
Bindon, B.M., Blanc, M.R., Pelletier, J., Terqui, M. \& Thimonier, J. (1975) Preovulatory gonadotrophin and ovarian steroid changes in French sheep breeds different in fecundity. Does FSH stimulate follicles? Proc. Aust. Endocr. Soc. 18, 64, Abstr.

LAND, R.B. (1976) The sensitivity of the ovulation rate of Finnish Landrace and Blackface ewes to exogenous oestrogen. J. Reprod. Fert. 48, 217-218.

Land, R.B., Pelletier, J., Thimonier, J. \& Mauléon, P. (1973) A quantitative study of genetic differences in the incidence of oestrus, ovulation and plasma luteinizing hormone concentration in the sheep. $J$. Endocr. 58, 305-317.

LAND, R.B., WHEELER, A.G. \& CARR, W.R. (1976) Seasonal variation in the oestrogen-induced $\mathrm{LH}$ discharge of ovariectomized Finnish Landrace and Scottish Blackface ewes. Annls Biol. anim. Biochim. Biophys. 16, 521-528.

Pant, H.C., Hopkinson, C.R.N. \& Fitzpatrick, R.J. (1977) Concentration of oestradiol, progesterone, luteinizing hormone and follicle-stimulating hormone in the jugular venous plasma of ewes during the oestrous cycle. J. Endocr. 73, 246-255.
SCARAmuzzI, R.J. \& BaIRD, D.T. (1977) Pulsatile release of luteinizing hormone and the secretion of ovarian steroids in sheep during anestrus. Endocrinology 101, 1801-1806.

Thimonier, J. \& Pelletier, J. (1971) Différences génétique dans le décharge ovulante $(\mathrm{LH}) \mathrm{chez}$ les brebis de race Ile-de-France; relations avec le nombre d'ovulations. Annls Biol. anim. Biochim. Biophys. 11, 559-567.

WheEler, A.G. \& LAND, R.B. (1977) Seasonal variation in oestrus and ovarian activity of Finnish Landrace, Tasmanian Merino and Scottish Blackface ewes. Anim. Prod. 24, 363-376.

Wheeler, A.G., Baird, D.T., Land, R.B. \& ScaraMUZZI, R.J. (1978) Genetic variation in the secretion of oestrogen in the ewe. J. Endocr. 75, 337-338.

Yuthasastrakosol, P., Palmer, W.M. \& Howland, B.E. (1975) Luteinizing hormone, oestrogen and progesterone levels in peripheral serum of anoestrous and cyclic ewes as determined by radioimmunoassay. J. Reprod. Fert. 43, 57-65.

Received 16 December 1977 